\title{
Economic Knowledge of Korean Elementary School Students: Contributing Personal Factors and Relative Weakness
}

\author{
Hahn, Jinsoo \\ (Inchon National University of Education)
}

\begin{abstract}
For many years, educators of economics have maintained the importance of economic education in school. Having shown a rapid economic growth for the last 4 decades, the Korean government has also called attention to effective economic education in schools. With numerous empirical studies (Derosier and Schuck, 1970; Kourilsky, 1979, 1987; Walstad, 1980) supporting that economics can be taught successfully to students at the elementary school level, the spotlight of economic education in Korea is now shifting to the lower grades of students from college students and adults.
\end{abstract}

Just like other areas of education, economics also requires understanding basic concepts for further development of economic knowledge and reasoning. Then it is quite natural for the primary goal of Korean economic education to be the teaching of fundamental economic concepts to elementary school students. While there has been considerable concern about economic education in Korean elementary schools, expressed by policymakers as well as educators, no study of the outcome from such a focus has been undertaken.

The purpose of this study is to measure economic knowledge, and identify relative strengths and weaknesses in Korean young children's understanding of economic concepts, by examining the results of a 20 -item multiple-choice test taken in 1999. This study also attempts to analyze the important personal factors that account for the level of economic knowledge of Korean elementary school students.

\section{Measuring Economic Knowledge}

A sample of 527 students in the Gyonggi and Inchon region was selected from students in grades 5 and 6 . Students in grades $\mathrm{K}$ through 4 were excluded from the test since economics content is mainly taught in the fifth grade textbooks in Korea. Questionnaires were designed and made to measure the economics understanding of elementary students required by Korean standard, which is basically similar to the Master Curriculum Guide in Economics of the U.S.

The test questions can be broken down into four distinct content categories: fundamental economic concepts, micro- economic 
concepts, macrocconomic concepts, and inter national cconomic concepts. Threc quarters of the questions covered cconomic fundamentals and microcconomics, recognizing that instruc tion at the fifth and sixth grade levels in Korca usually focused on rational consump tion and economic way of thinking, rather than a macrocconomic world. The questions were written in plain cxpressions without using cconomic terminologics that are not shown in textbooks, to avoid the possibility of students' failure to understand the ques tions themselves. (The test questions are available upon request.)

\section{Item Analysis}

The mean score for the sample was 61.1 points(percent), with the standard deviation of
15.4. Because students have different degrees of understanding of different aspects of cconomics, it is necessary to know how Korean elementary students performed on specific parts of the test, particularly which cconomic concepts they understand best and least. To identify conomic concepts of relative strength and weakness in student understanding, the percentage of correct responses was used in this study. Table 1 reports not only the average percentage of correct responses for cach question, but the cconomic concepts of relative strength and weakness.

Test results indicate that Korcan elemen tary students wore very weak in their understanding of some fundamental cconomic concepts such as international trade, profit, bank interest rates, and ownership of private

Table 1 Percentage of Correct Responses

\begin{tabular}{ccccc}
\hline \hline \multirow{2}{*}{ Item } & \multirow{2}{*}{ Related Economic Concepts } & \multicolumn{3}{c}{ Pcrcent Corrcct } \\
\cline { 3 - 5 } & Scarcity & Male & Female & Tolal \\
\hline 1 & Scarcity and Choice & 85 & 55 & 59 \\
2 & Opportunity Cost & 84 & 92 & 88 \\
3 & Markets and Prices & 57 & 56 & 88 \\
4 & Demand and Prices & 62 & 63 & 62 \\
5 & Supply and Prices & 70 & 69 & 70 \\
6 & Consumption and Production & 73 & 76 & 75 \\
7 & Consumption and Production & 80 & 82 & 81 \\
8 & Market Economy and Incentives & 61 & 63 & 61 \\
9 & Competition and Profit & 29 & 22 & 25 \\
10 & Banks and Profit & 12 & 50 & 16 \\
11 & Value Added and Transactions & 80 & 84 & 82 \\
12 & Circular Flow of Income and Product Market & 83 & 83 & 82 \\
13 & Circular Flow of Income and Factor Market & 91 & 92 & 91 \\
14 & Circular Flow of Income and Distribution & 48 & 55 & 51 \\
15 & Exchange and Money & 69 & 75 & 72 \\
16 & Ownership of Private Property & 40 & 37 & 39 \\
17 & Division of Labor and Productivity & 17 & 19 & 18 \\
18 & Trade and Comparative Advantage & 23 & 20 & 22 \\
19 & Trade and Barricrs to Trade & 21 & 11 & 19 \\
20 & & &
\end{tabular}


property. The percentage of correct responses of the questions concerning these concepts ranged from 19 to 46 . The lower scores in these cconomic concepts may be a result of more difficult questions in such areas. Even though the degree of difficulty is considered, it seems to be hard to deny that Korean students are relatively weak in those arcas.

In particular, Korcan elementary students did worst in international trade. Only about 20) percent of students answered correctly to the questions regarding notions and bencfits of international tradc. Many Korcan clementary students lacked an adequate understanding of the benefits of trade, but believed that only exports would be beneficial while imports would be harmful to the Korcan economy. The share of students who answered that Korcan products should be purchased irrespective of their low quality and/or high prices amounted to 70 percent. These students did not recognize that buying domestic goods rather than imported goods, even though domestic goods were inferior to imported goods, would not contribute to the competitiveness and the growth of domestic firms in the long run. Instcad, to these students, there was a tendency to fecl a sense of guilt if they bought imported goods when domestic goods were available.

These results may be so natural in that the Korean economy has grown by export led policies, supported by the government. To this purpose, the government often used trade barricrs to restrict international trade and advocated the rationales for protectionism. Because this protectionism was so widely used and pervaded into daily life, many Korcan people, including teachers, still tend to belicve that protectionist policies will bencfit the Korean cconomy and that imports should be discouraged. They do not understand that free trade promotes a mutually beneficial division of labor among nations, and that froc and open trade allows each nation to expand its production and consumption possibilitics, raising our living standard. This biased view on international trade has naturally pervaded into young children's minds.

Students did poorly on the notion of profit as well, although profit plays a central rolc for firms to operate in a market cconomy. The following explanation may be possible for this result. Many Korcan students do not understand that firms can carn profit by producing what consumers want most, and that competitive markets force firms to produce goods and services consumers demand at the lowest prices that will cover costs. In addition, many elementary school students (18 percent) answered that banks should not make economic profit. To thesc students, banks are not private businesses sceking cconomic profit, but sometimes government owned. (Other examples of students incorrectly answering questions were that firms could always increase profit by raising prices ( 15 percent), and that profit increascd with more competition (21 percent).

It is still true that many Korcan elementary school students regard firms making a lot to be undesirable companics or even immoral. This may result from the fact that some Korean firms that made huge profit exploited workers and uscd unfair transactions during rapid cconomic growth, when the market system was not solidly in place in the Korcan cconomy. These bad practices have made people cast a suspicious 
glance at high profit carning firms.

Students were also weak in responding to questions regarding bank interest rates, and only 46 percent of students correctly responded. It was generally recognized by most students that, if someone leaves money in the bank for a period of time, he can carn interest. IIowever, some of them are unaware of the fact that banks charge more for the use of moncy as loans than they pay on customers' deposits to carn a profit.

About 14 percent of students answercd that interest would be the same on deposits and loans. $\Lambda$ s Jahoda (1981) found, these students tend to regard the principles regulating bank transactions as the same as those between friends. Just like you return the same amount after you borrow money from your friend, it is fair to these students that banks charge the same interest on both deposits and loans. Jahoda also noted that it was difficult for students to begin to separate their vicws of personal arrangements from the more impersonal arrangements of socicty, and to recognize the need for a bank to charge more on loans to make a profit.

Nlthough the notion of private property is fundamental to understanding the opcration of the market cconomy, Korcan elementary students were also very ignorant of private property. Only 39 percent of students answered correctly. This result confirms the findings of Danziger (1958) and Berti, et al. (1982). To some students (34 percent), the owner of the bus was the bus driver or the passenger. It is likely that, to these students. the owner of property is the person who is in spatial contact with the object or who controls the object. The share of students who responded that the owner of the bus was the government amounted to 23 percent. It is likely that these students are confused with a subway system operated by the government in Korea, and thereby they belicve that another form of mass transportation, a bus, is also owned by the government.

\section{Gender Differences}

Table 1 also shows male femalc differences in the areas of relative strengths and weaknesses. Female students did better than male students in the areas of scarcity, opportunity cost, banks and profit, and circular flow of income. On the other hand, the areas male students did better than female students are profit and international trade.

It should be pointed out that it is not completely clear why gender differences in students' understanding of economics were found in these arcas of concepts. More reliable data is needed and more refined tests must be developed before this question can be answered.

\section{Personal Factors Affecting Economic Knowledge}

\section{The Model}

A simple linear regression model was employed to identily factors that influence the level of economic knowledge, and to determine the effect that those factors might have on a student's economics literacy score. In general, the model of learning examines 
test scores as output as a function of various inputs. The model can be summarized as

$$
Y=a_{0}+\sum_{i=1} a_{i} X_{i}+e,
$$

where $Y$ is the students' understanding of economics as measured by the test score, $X_{i}$ 's are key students' characteristics such as gender, grade, and sex, $a_{i}^{\prime}$ s are the coefficients for the independent variables, and $e$ is the error term of the equation.

The dependent variable, test scores, are evaluated between 0 and 100 . The independent variables used in the model mainly came from previous studies of factors influencing the understanding of economics of various groups. Some personal attributes, believed to be significant factors, could not be used as independent variables in this study, because collecting independent variable data for individual students was entirely based upon his or her responses. The data includes family income (not precisely known to students), IQ (not available), and students' general test score (there are no national exams for elementary school students in Korea). As a result, the limited independent variables used in estimating the equation were:

$G R A D E=$ grade level $(1$ if sixth grade; 0 if fifth grade)

GENDER $=\operatorname{sex}(1$ if femalc; 0 if malc $)$

FAMILY $=$ number of adults in the lamily ( 1 if 3 or more adults; 0 if 1 or 2 adults)

$A C A F 1, A C A F 2$ = father education ( $A C A F 2=1$ if college education: $A C A F 1=1$ if high school education; $A C A F 1=A C A F 2$
$=0$ otherwise)

$A C A M 1, A C A M 2$ = mother education ( $A C A M 2-1$ if college education; $A C A M 1-1$ if high school education; $\Lambda C \wedge M 1=\Lambda C \wedge M 2$ $=0$ otherwise)

NEWS = frequency of reading children's newspapers

SS1, $\quad$ SS2 = preference for social studies ( $S S 2^{-1}$ if positive; $S S 1^{-1}$ if neutral; $S S 1^{-}$ $S S 2=0$ otherwise)

$F A V=$ the subject for which a student has the most positive attitude( 1 if social studies; 0 otherwise)

MONAM1, MONAM2 = amount of monthly pocket moncy ( $M O N A M 2=1$ if greater than 10 thousand won; MONAM $1=1$ if 5-10 thousand won; MONAM1=MONAM2 -0 otherwise)

The grade level variable was included to measure differences in the age of students. The sign of the coelficient on GRADE is of interest since there are two contrasting effects. Children improve their economic knowledge with formal instruction and with increasing maturity (Schug, 1991). According to this elfect, a positive coeflicient is expected. On the other hand, retention declines over time. The majority of contents of economics appear in fifth grade textbooks in Korea. Therefore, sixth graders would show lower scores than fifth graders if students' economic knowledge depreciates over time. This effect would yicld a negative coelficient. The estimated coefficient would measure the net effect of age on economic knowledge. Therefore, no predictions on the sign of the coefficient were made for this variable.

The student sex variable was entered to control the dilferences in sex of students. 
Nlthough the existing empirical cvidence on the role of gender in cconomic knowledge has resulted in a varicty of findings, no difference betwoen males and females was found for clementary school students. Instead, many studies (MacDowell et al., 1977; Walstad and Soper, 1988; IIcath, 1989; Gleason and Van Scyoc, 1995; Walstad, 1997) found significant differences in learning cconomics in favor of males, only at the high school or college level. Thus, I tricd to test the hypothesis that there would be no male female difference in the test score among Korean elementary school students.

$\Lambda$ family dummy variable would capture the effect of adults in a family on students' economic knowledge. The student's level of cconomic knowledge would be expected to increase with additional exposure to daily expericnce and informal cconomic cducation received within a student's family environment. Thus, I hypothesized that the variable would have a positive coefficient.

The family cducation variable was included to measure the effect of parents' cducational levels on test scores. The inclusion of this input variable was based on the assumption that students at higher sociocconomic levels, as measured by parents' cducational levels. would perform better on an cconomics test than would students at lower levels. This variable was classificd into three categories: middle school cducation, high school cducation, and college cducation. The cducation variable was also defined into two separate groups, mothers and fathers, in order to ascertain which parent was more responsible for the children's understanding of cconomics.

I included the NEWS variable to estimate the effects on cconomic knowledge of reading newspapers. Because economics is a social science concerned chiefly with the problems of the real world, economic knowledge can also be obtained from reading newspapers, as well as from formal cconomics instruction in the classroom. In addition, using newspapers is now a widely used teaching method in Korean elementary schools. Therefore, I hypothesized that conomic knowledge would rise with frequent reading of children's newspaper articles.

A preference variable was included to measure the effect of students' attitudes toward social studies on economic knowledge. Because general education research indicates that attitudes loward a subject tend to influence a subject's score, I predicted that this variable would have a positive coefficient. Two types of information were collected to identify students' attitudes; one was the degree of preference for social studies, categorized as positive, neutral, and negative, and the other was the subject for which a student had the most positive preference.

Finally, I included a variable to estimate the effects on economic knowledge of income. which was expected to demonstrate a positive relationship with the score. However, the amount of pocket money was used as a proxy variable, because the student's family income data was unavailable and students were uninformed of their individual family income.

\section{Sample Characteristics}

There was an even split of fifth and sixth grade students, and a nearly even split of male and female students. About 84 percent 
of the sample students lived in a family of 1 or 2 adults, while 13 percent lived in a family of 3 or more adults. Thirty three percent of fathers and 19 pereent of mothers in the sample have obtained a collcge cducation, but more than half of parents have obtained a high school cducation (55 percent of fathers and 66 percent of mothers). While fifty five pereent of students did not read children's newspapers at all, the proportion of students who read them everyday was 20 percent (no newspapers on Sundays).

More than half of the students had a neutral preference for social studies, with 28 percent having positive, and 16 percent having negative preference. Social studies was the most preferred subject for 8 percent of the students. Taking a close look at the data also suggested a significant difference in preference between male and female students. The ratio of students with positive preference for social studies was higher for males ( 34 percent) than for females (24 percent). The gender difference was also found in the subject that students liked most. Nbout 10 percent of male students had the most positive preference for social studies, compared with 6 percent for female students. It might be concluded from these statistics that male students had a more positive preference for social studies than female students in Korca. Finally, 50 percent of students received monthly pocket moncy of more than 10 thousand won (approximately 8 U.S. dollars if the exchange rate when the data was collected is applied), with 25 percent receiving 5 to 10 thousand won, and 20) percent recciving less than 5 thousand won.

\section{Empirical Results}

$\Lambda$ s France, et al. (1989) argued, logit models do not improve the test results significantly, because signs and $t$ statistics reveal the same pattern as OLS results. This study also used OLS methods, and the estimation results are provided in Table 2. Each of the four equations shown in the table represents a different set of estimators.

The constant represents the mean score of fifth grade male students who lived with 1 or 2 adults, whose parents have oblained a middle school education, who did not read newspapers at all, did not like social studies, and received less than 5 thousand won as a pockel money a month. The means varied from 48.3 to 50.2 points.

For all equations, the father education variable was statistically significant and had a positive sign. Students with fathers who have obtained a college education scored 8.6-9.6 points higher than students of fathers who have no college instruction. On the other hand, children with fathers who have high school instruction had more knowledge (3.1-4.4 points higher) than children with fathers who have no high school instruction, but the difference was statistically insignificant. If we speculate the parents' education variable as a proxy for students' intelligence, this result is consistent with the findings of Walstad and Soper (1989), Glcason and Van Scyoc (1995), and Walstad (1997). In contrast, a mother's educational level with a positively estimated coeflicient proved to be statistically insignificant in explaining a student's cconomics score in all equations. Why a student's economic knowledge was closely and significantly related to the father's educational level, but not the mother's, is very difficult to answer 
Table 2 OLS Regression Results

\begin{tabular}{|c|c|c|c|c|}
\hline \multirow{2}{*}{ Independent Variables } & \multicolumn{4}{|c|}{ Equations } \\
\hline & (1) & $(2)$ & (3) & (1) \\
\hline Constant & $\begin{array}{l}18.25 * * * * \\
(11.28)^{2}\end{array}$ & $\begin{array}{l}18.31 * * * * \\
(11.31)\end{array}$ & $\begin{array}{l}50.17 * * * * \\
(16.20)\end{array}$ & $\begin{array}{l}19.97 \% * * \\
(16.21)\end{array}$ \\
\hline$G R \Lambda D E$ & $\begin{array}{l}1.81 \\
(1.28)\end{array}$ & $\begin{array}{r}1.80 \\
(1.27)\end{array}$ & $\begin{array}{r}1.72 \\
(1.24)\end{array}$ & $\begin{array}{r}1.80 \\
(1.30)\end{array}$ \\
\hline$G E N D E R$ & $\begin{array}{r}1.18 \\
(0.85)\end{array}$ & $\begin{array}{r}1.17 \\
(0.84)\end{array}$ & $\begin{array}{r}0.69 \\
(0.50)\end{array}$ & $\begin{array}{r}0.74 \\
(0.54)\end{array}$ \\
\hline FAMILY & $\begin{array}{c}3.19 * \\
(1.73)\end{array}$ & $\begin{array}{l}3.13 * \\
(1.70)\end{array}$ & $\begin{array}{r}2.61 \\
(1.32)\end{array}$ & $\begin{array}{r}2.63 \\
(1.33)\end{array}$ \\
\hline$A C A F 1$ & $\begin{array}{r}1.21 \\
(1.11)\end{array}$ & $\begin{array}{r}1.37 \\
(1.19)\end{array}$ & $\begin{array}{r}3.11 \\
(1.08)\end{array}$ & $\begin{array}{r}3.17 \\
(1.11)\end{array}$ \\
\hline$A C A F^{2}$ & $\begin{array}{l}9.60 \% * \% \\
(2.94)\end{array}$ & $\begin{array}{l}9.64 * * * \\
(2.95)\end{array}$ & $\begin{array}{l}8.58 \% * * * \\
(2.69)\end{array}$ & $\begin{array}{l}8.67 \% * * \\
(2.72)\end{array}$ \\
\hline$\Lambda C \wedge M 1$ & $\begin{array}{r}0.78 \\
(0.32)\end{array}$ & $\begin{array}{r}0.69 \\
(0.28)\end{array}$ & $\begin{array}{r}0.52 \\
(0.22)\end{array}$ & $\begin{array}{r}0.40 \\
(0.17)\end{array}$ \\
\hline$A C A M 2$ & $\begin{array}{r}-1.81 \\
(-0.58)\end{array}$ & $\begin{array}{r}-1.88 \\
(-0.61)\end{array}$ & $\begin{array}{r}-1.77 \\
(-0.58)\end{array}$ & $\begin{array}{r}-1.90 \\
(-0.62)\end{array}$ \\
\hline NEWS & $\begin{array}{r}0.04 \\
(0.16)\end{array}$ & $\begin{array}{r}0.04 \\
(0.16)\end{array}$ & $\begin{array}{r}0.02 \\
(0.08)\end{array}$ & $\begin{array}{r}0.03 \\
(0.12)\end{array}$ \\
\hline$S S 1$ & $\begin{array}{l}3.633^{*} \\
(1.86)\end{array}$ & $\begin{array}{l}3.59 \% \\
(1.84)\end{array}$ & $\begin{array}{l}3.68 \% \\
(1.89)\end{array}$ & $\begin{array}{l}3.84 * * \\
(1.98)\end{array}$ \\
\hline$S S 2$ & $\begin{array}{l}8.81 * * * \\
(3.96)\end{array}$ & $\begin{array}{l}9.68 * * * \\
(1.55)\end{array}$ & $\begin{array}{l}9.35 * * * * \\
(1.22)^{2}\end{array}$ & $\begin{array}{l}10.22 \times 3 \times \\
(1.88)\end{array}$ \\
\hline$F \wedge V$ & $\begin{array}{r}3.35 \\
(1.89)\end{array}$ & - & $\begin{array}{r}2.62 \\
(0.96)\end{array}$ & - \\
\hline MONAM1 & $\begin{array}{l}3.41 * \\
(1.70)\end{array}$ & $\begin{array}{l}3.44 * \\
(1.73)\end{array}$ & - & - \\
\hline MONAM2 & $\begin{array}{r}0.29 \\
(0.17)\end{array}$ & $\begin{array}{r}0.35 \\
(0.20)\end{array}$ & - & - \\
\hline$R^{2}$ & 0.10 & 0.10 & 0.09 & 0.09 \\
\hline$N$ & 466 & 467 & 484 & 486 \\
\hline
\end{tabular}

Notes: The dependent variable is the test score, and $N$ varies since there are missing variables in the sample. The $t$-values are shown in parentheses.

$*$ Significant at the .10 level; ** significant at the .05 level; *** significant at the .01 level. 
here. To my knowledge, one explanation might be the possibility of multicollinearity between $A C A F$ and $A C A M$. However, the mother's education still turned out to be insignificant when the equation was re estimated without the father's education variable, although the results are not reported.

The student's preference for social studies contributed significantly to his greater understanding of economic content across all equations. Students who had a positive preference for sociál studies outperformed students who did not. The estimation results showed that students with a positive preference scored 8.8-10.2 points higher, and students with a neutral preference scored 3.6-3.8 points higher respectively than students with a negative preference. These results are not surprising because studies of general education have consistently shown that attitude influences school performance.

Less significant variables in explaining students' economic knowledge were pocket money, and the number of adults in a family. Both of them had positive effects on economic knowledge, as was expected, but the coefficients were significant only at the 10 percent level in equations (1) and (2). Students who lived with 3 or more adults scored 2.6-3.5 points higher than students who lived with 1 or 2 adults. The most likely explanation for this effect is that larger families provide more opportunities for experiencing consumption activities, and learning economic knowledge from family members.

P'ocket money should be particularly noted. Students who received pocket money of 5-10 thousand won were more knowledgeable about economics than the other groups (by 3.4 points). Surprisingly, students who received pocket money of more than 10 thousand won failed to show better performance than the other students. Nlthough the specific reasons for these results are unclear, my best speculation is that possibly the students with enough pocket moncy have little incentives for rational consumption.

The other variables, believed to be factors, proved to be statistically insignificant in all cquations. First, the grade level variable had a positive sign, meaning that sixth graders had greater progress in cconomic knowledge (by 1.71 .8 points) than fifth graders, but the difference was statistically insignificant. $\Lambda$ plausible explanation for this result is that the "maturity effect", whereby students' cconomic knowledge increases with maturity, was almost cancelled out by "lasting effect", whereby sixth graders lose some economic knowledge they learned in fifth grade. Niternatively, one year may be too short to significantly contribute to the maturity and the cconomics understanding of elementary school students.

The gender variable proved to be insignificant and no difference was found between males and females in economic knowledge. This finding is consistent with the results that the difference between males and females in learning cconomics is not found for clementary school students (Davison and Kilgore, 1971: Buckles and Frecman, 1983; Kim et al., 1997). $\Lambda$ typical explanation for gender differences is a cultural environment that discourages females from taking an interest in the business world (Sicgfricd and Strand, 1977). If this 
explanation is correct, one would expect that clementary school students are too young for these effects to be of value, thercby resulting in no significant difference between males and females.

It was expected that reading newspapers would contribute to the students' cconomic literacy; however, the frequency of reading children's newspapers had no significant impact on economics understanding. The children's nowspapers may not contain relevant cconomic articles in both contents and quantity. The frequency of reading newspapers may have an effect on cconomic knowlcdge if it is measured by an essay exam, rather than a multiple choice exam.

The cocfficients of determination $\left(R^{2}\right)$ for all equations were low, which was not completely unexpected because the regression model used in this study had very limited personal characteristics as explanatory variables. Some important personal characteristics, which proved to be significant in earlier studies, such as students' general test score, IQ, and family income, could not be used in the estimation because the data was either unavailable, or unreliable.

Another possible explanation for the low $R^{2}$ is that the model in this study focused only on personal characteristics. That is, adding independent variables such as school systems, teachers' characteristics, demo graphic leatures, and instructional factors may greatly contribute to improving the explanatory power of elementary students' cconomic knowledge. The effort to collect more reliable information and refined data on these variables will have to precede the effort to construct and estimate a model.

\section{Conclusions}

Several conclusions can be drawn from this study. First, Korcan elementary school students are very weak in their under standing of some cconomic concepts such as international trade, profit, bank interest rates, and ownership of private property. Negative attitudes toward profit influenced by some monopolistic firms, the prejudice against imports generated and cducated by the government policies, and the frequent intervention by the government into the market, appear to be responsible for thesc results.

The study also suggests that the father's cducational level, and student's preference for social studies are the most influential personal factors that account for the level of cconomic knowledge. On the other hand, some attributes such as grade level, gender, and frequency of reading children's newspapers are shown to be insignificant. These findings naturally recommend that to identify other factors affecting Korcan students' cconomic knowledge, this study noeds to be expanded to include a wider array of variables. IIowever, more refined data need to be gathered before additional rescarch can be undertaken with any degreo of certitude.

These results imply that elementary school teachers who want to improve students' economic knowledge would be wise to understand their weakness, and to employ adcquate educational strategies and matcrials that contribute to overcoming learning hurdles associated with some confusing cconomic concepts. 


\section{References}

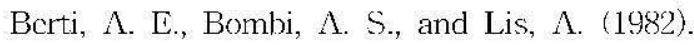
The child's conceptions about means of production and their owners. European Journal of Social Psychology, 12, 221239.

Buckles, S., and Frecman, V. (1983). Male female differences in the stock and flow of cconomic knowledge. Review of Economics and Statistics, 65(2), $3553,358$.

Danziger, K. (1958). Children's carliest conceptions of cconomic relationships. Journal of Social Psychology, 47, 231240.

Davison, D. G., and Kilgore, J. II. (1971). A model for evaluating the effectiveness of cconomic cducation in primary grades. Journal of Economic Education, 3(1), 1725.

Derosicr, R. R., and Schuck, R. F. (1970). A comparison of the effectiveness of two social studies instructional programs upon first grade level pupil achicvement in cconomics. Educational Leadership, 27, 815824 .

France, J., Summary, R., and Vascgh Daneshvary, N. (1989). The impact of cconomic education courses on the knowledge and retention of knowledge of sccondary and primary school tcachors. Journal of Economic Education, 20(4), 346354.

Gleason, J., and Van Scyoc, L. J. (1995). A report on the cconomic literacy of adults. Journal of Economic Education, 26(3), 203210 .

IIcath, J. $\Lambda$. (1989). An cconometric model of the role of gender in cconomic education. American Economic Review, 79(2), 226230 .
Jahoda, G. (1981). The development of thinking about cconomic institutions: the bank. Cahiers de Psychologie Cognitive, 1(1), 5573 .

Kim, S., Dick, J., and Reiser, M. L. (1997). Determinants of achicvement of cconomic concepts by elementary school students. Journal of Economic Education, 28(2), 100121.

Kourilsky, M. (1979). Optimal intervention: an cmpirical investigation of the rolc of the teacher in experience based instruction. Journal of Experimental Education, 47(4), 339345 .

Kourilsky, M. (1987). Children's learning of cconomics: the imperative and the hurdles. Theory into Practice, 26(3), 198205.

MacDowell, M. A., Senn, P. R., and Soper, J. C. (1977). Does sex really matter? Joumal of Economic Education, 9(1), 2833.

Schug. M. C. (1991). The development of students' economic thought: implications for instruction. In W. B. Walstad, and J. C. Soper (cds.), Effective Economic Education in the Schools. Washington, D.C.: National Education $\Lambda$ ssociation.

Sicgfricd, J. J., and Strand, S. (1977). Sex and the cconomic student. Review of Economics and Statistics, 59(2), 247249.

Walstad, W. B. (1980). The impact of "trade offs" and teacher training on cconomic understanding and attitudes. Journal of Economic Education, 12(1), 4148.

Walstad, W. B. (1997). The effect of cconomic knowledge on public opinion of cconomic issues. Journal of Economic Education, 28(3), 195205.

Walstad, W. B., and Soper, J. C. (1988). A report card on the economic literacy of 
L.S. high school students. American Economic Review, 78(2), 251255.

Walstad, W. B., and Soper, J. C. (1989). What is high school cconomics? Factors contributing to student achicvement and attitudes. Journal of Economic Education, 20(1), 2338. 
초록

\title{
한국 초등힉생들의 경제지식: 결정요인과 상대적으로 이해도가 낮은 경제 개넘
}

\author{
한 진 수 \\ (인천교육대학교)
}

이 연구는 객관식으로 구성된 경제지식 검사 지를 이용하여 한국 초등학생들의 경제지식 수 준을 측정하고, 이돌이 상대적으로 어떤 경제 개넘을 잘 이해하고 있으며 어떤 경제 개념을 잘 이해하고 있지 못한지를 분석하었다. 또 이 연구는 어떤 개인적 요인들이 초등학생들의 경 제지식 수준에 영향을 미치는지를 검증하었다. 모두 527명의 5학년과 6학년을 대상으로 검사 를 실시하였는데, 이들은 100 점 만점에 평군 61.1점을 언었다. 겁사 결과 한국 초등학생들은 무역, 이윤, 이자율, 개인재산의 소유건과 같은
경제 개념에 대한 이해도가 매우 낮음을 알 수 있었다. 성별로는 여학생이 희소성, 기회비용, 은행의 이윤, 꾹민소득에서 낲학생보다 높은 점 수를 얻었고, 남학생은 이윤과 무역에서 여학생 보다 놇은 점수를 얻있다. 초등학생돌의 경제지 식에 영향을 미치는 개인적 요인들을 회귀분석 을 통해 검증한 결과 아버지의 고육정도와 사 회과목을 좋아하는 정도가 가장 중오한 오인들 로 밝혀졌다. 이에 비해 학년, 성, 어린이신문의 구독과 같은 요인들은 통계적으로 유의성을 찾 기 어려웠다.

Key Words : economic education, economic knowledge, elementary students, trade, profit, interest rates, ownership 